\title{
Karakteristik Respon FPSO Konversi Tanker Ukuran 310 M
}

\author{
Response Characteristics of FPSO Conversion of Tanker Size 310 M
}

\author{
Luh Putri Adnyani ${ }^{1, *}$, Rima Gusriana Harahap ${ }^{1}$ \\ ${ }^{1}$ Teknik Kelautan, Jurusan Sains Teknologi Pangan dan Kemaritiman, Institut Teknologi Kalimantan, 76127, Indonesia
}

* Corresponding author : luhputria@itk.ac.id

Tel.: +62-812-1711-9059; fax.: +62-54-285-308-00

Received: Jan 10, 2019; Accepted: Apr 27, 2019.

DOI: 10.25299/saintis.2019.vol19(1).2524

\section{Abstrak}

Floating Production Storage and Offloading (FPSO) sudah banyak beroperasi di seluruh dunia dan akan lebih banyak lagi yang akan dibangun untuk eksplorasi dan eksploitasi laut dalam. Penelitian ini menunjukkan respon dari FPSO dengan ukuran $310 \mathrm{~m}$ lpp dan membandingkan nilai respon yang didapat dengan experiment yang didapatkan oleh Kim. Penelitian dimulai dengan memodelkan FPSO sesuai dengan data yang ada dan melakukan analisa dengan menggunakan pemodelan numerik. Dari hasil analisa didapatkan bahwa respon dari FPSO sangat dipengaruhi oleh gerakan dari FPSO akibat gelombang dan bervariasi terhadap sudut. Respon gaya geser longitudinal maksimum pada sudut $120^{\circ}$. Respon gaya geser transversal maksimum pada sudut $90^{\circ}$. Respon gaya geser vertikal maksimum pada sudut $90^{\circ}$. Respon roll moment maksimum pada sudut $90^{\circ}$. Respon pitch moment maksimum pada sudut $120^{\circ}$. Respon yaw moment maksimum pada sudut $60^{\circ}$.

Kata Kunci: Floating Production Storage and Offloading, respon, gaya geser, moment

\begin{abstract}
Floating Production Storage and Offloading (FPSO) has a lot of operating around the world and there will be more to be built for the exploration and exploitation of deep sea. This study shows the response of the $310 \mathrm{~m} \mathrm{LPP} \mathrm{FPSO} \mathrm{and} \mathrm{compares} \mathrm{the} \mathrm{responses} \mathrm{with} \mathrm{experiment}$ result by Kim [1]. The study begins by modeling the FPSO in accordance with the existing data and to analyze using numerical modeling. From the results found that the response of the FPSO is strongly influenced by the heading and motion of the FPSO. Maximum longitudinal shear force in $120^{\circ}$, maximum transverse shear force in $90^{\circ}$, maximum vertical shear force in $90^{\circ}$, maximum roll moment in $90^{\circ}$, maximum pitch moment in $120^{\circ}$, maximum yaw moment in $60^{\circ}$.
\end{abstract}

Keywords : Floating Production Storage and Offloading, respon, shear force, moment

\section{PENDAHULUAN}

Floating Production Storage and Offloading (FPSO) sudah diinstal dengan sukses dan beroperasi di seluruh dunia selama 10 tahun terakhir, dan ke depan lebih banyak FPSO yang akan didesain dan diinstal. FPSO ditempatkan di daerah yang spesifik dengan pembebanan dinamis tertentu. FPSO harus didesain untuk memenuhi persyaratan di semua kondisi loading dan offloading.

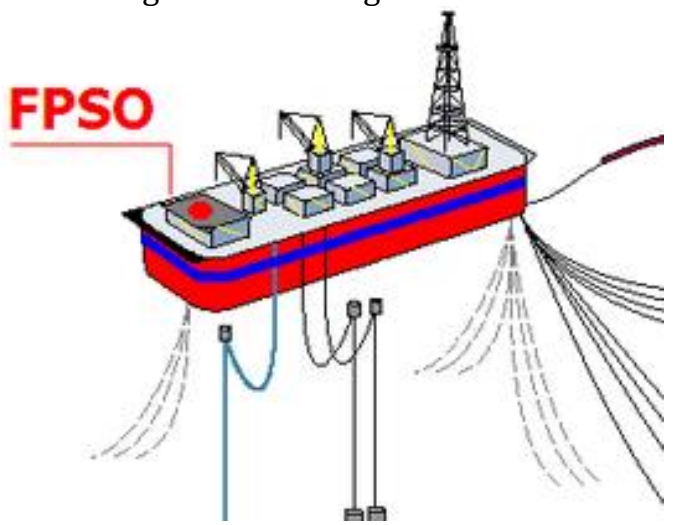

Gambar 1. Floating Production Storage and Offloading (FPSO), Sumber: Wikipedia
Beberapa penelitian sebelumnya mengamati karakteristik dinamis dari FPSO akibat angin, gelombang dan arus. Kim, dkk [1] mengamati respon FPSO dalam prediksi laut badai dengan program analisa dinamis couple kapal, mooring dan riser yang dibandingkan dengan pengukuran di wave tank. Tanker dan FPSO dihubungkan dengan system turret dan FPSO sendiri di mooring dengan 12 rantai-polyester-rantai di kedalaman $6000 \mathrm{ft}$. Hai Hong Sun dan Yong Bai [2] membuat penelitian tentang keandalan hull FPSO berdasarkan variasi waktu untuk mengembangkan kiriteria desain dan perencanaan inspeksi yang rasional.

Dalam penelitian Amlashi dan Moan [3] dibahas tentang pengaruh kombinasi bending global dan double bottom, implikasi perhitungan pressure dengan menggunakan rule yang berbeda dan menganalisa distribusi tegangan nya. Dari beberapa penelitian sebelumnya, perlu dicari respon dari FPSO akibat beban gelombang dan mencari hubungan antara respon yang didapat pada FPSO ketika kondisi air tenang dan ketika dipengaruhi oleh gelombang. 
Adapun tujuan dari penelitian ini adalah untuk mengetahui respon FPSO pada kondisi air tenang dan membandingkan respon FPSO pada saat terdapat gelombang dengan variasi sudut datang gelombang dan perbedaan nya terhadap hasil pada FPSO yang digunakan dalam jurnal Archandra Tahar dan M.H. Kim. 2003. Hull/mooring/riser coupled dynamic analysis and sensitivity study of a tankerbased FPSO, diasumsikan sebagai struktur baru, dimodelkan sebagai rigid body, sehingga kekuatan dari FPSO tidak diperhitungkan; distribusi massa di atas FPSO dipertimbangkan dalam pemodelan melalui justifikasi peneliti; dan pembebanan untuk FPSO akan diambil dari beban lingkungan periode 100 tahun di Gulf Mexico.

\section{METODOLOGI}

\section{Perilaku Gerak Struktur Terapung}

Setiap struktur terapung yang bergerak di atas permukaan laut selalu mengalami gerakan osilasi. Gerakan osilasi ini terdiri dari 6 (enam) macam gerakan, yaitu 3 (tiga) macam gerakan lateral dan 3 (tiga) macam gerakan rotasional dalam 3 (tiga) arah sumbu yang ditunjukkan dalam Gambar 2. di bawah. Macam-macam grakan itu meliputi:

1. Surge, gerakan transversal arah sb. $\mathrm{x}$.

2. Sway, gerakan transversal arah sb. $y$.

3. Heave, gerakan transversal arah sb. z.

4. Roll, gerakan rotasional arah sb. $\mathrm{x}$.

5. Pitch, gerakan rotasional arah sb. $y$.

6. Yaw, gerakan rotasional arah sb. z.

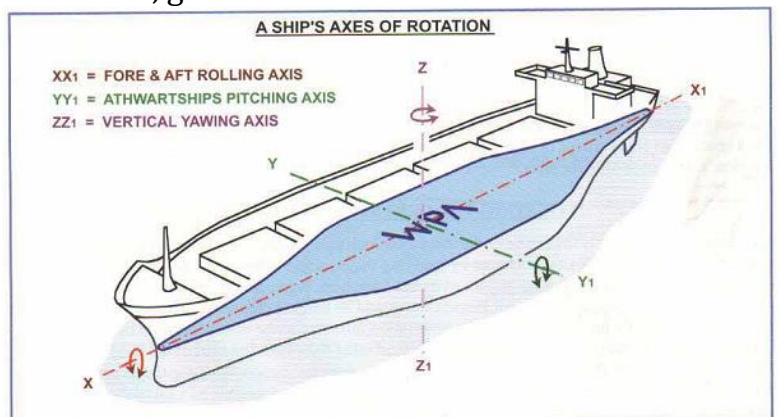

Gambar 2. Koordinat Gerakan Bangunan Apung Sumber dari Clark, I.C., [4]

Hanya 3 (tiga) macam gerakan, yaitu heaving, rolling dan pitching, yang merupakan gerakan osilasi murni karena gerakan ini bekerja dibawah gaya atau momen pengembali ketika struktur itu terganggu dari posisi kesetimbangannya. Pada kasus surging, heaving, dan yawing, struktur tidak kembali pada posisi kesetimbangannya semula jika terganggu, kecuali jika ada gaya atau moment pengembali yang menyebabkannya bekerja dalam arah berlawanan.

\section{Bending Moment dan Shear Force}

Gaya buoyancy diambil dari gaya hidrodinamis total pada bagian kapal, efek dari gerakan kapal pada tekanan hidrodinamis diabaikan[5]. Gaya buoyancy dihitung dengan mengkombinasikan dengan gaya gravitasi pada bagian kapal untuk menghitung gaya resultan, yang diintegralkan sepanjang kapal untuk menghasilkan gaya geser dan bending moment. Bending moment pada kapal dapat dibedakan menjadi 3 bagian, yaitu:

1. Vertical bending moment, menghasilkan defleksi pada sumbu y

2. Horizontal bending moment, menghasilkan defleksi pada sumbu z

3. Transverse bending moment, menghasilkan defleksi pada sumbu $\mathrm{x}$

Horizontal bending moment dapat disebabkan oleh gerakan rolling dan arah datang gelombang yang menyudut atau puncak gelombang berada pada satu sisi dari kapal dalam suatu phase. Beberapa eksperimen menunjukkan bahwa horizontal bending moment dan vertical bending moment memiliki besaran yang sama. Kecuali untuk kapal catamaran, kombinasi gaya hydrostatic dan hidrodinamis tidak menghasilkan bending moment secara signifikan pada bidang transversal. Tegangan resultan maksimum pada beberapa titik untuk menghitung vertical dan horizontal bending moment diberikan dengan rumus:

$$
\sigma=\sqrt{\left(\frac{M_{V} z}{I_{V}}\right)^{2}+\left(\frac{M_{H} y}{I_{H}}\right)^{2}}
$$

Dimana,

$M_{V} \quad$ = vertical bending moment

$M_{H} \quad=$ horizontal bending moment

$y=$ jarak dari sumbu $\mathrm{z}$ (horizontal)

$z \quad=$ jarak dari sumbu y (vertical)

$I_{V} \quad=$ moment inersia dari apda sumbu y

$I_{H} \quad$ = moment inersia pada sumbu $\mathrm{z}$

Masing-masing bending moment tersebut juga dapat dihitung dengan menjumlahkan ketiga komponen, yaitu:

1. Yang disebabkan oleh perbedaan distribusi dari berat dan buoyancy ketika berada di kondisi air tenang

2. Yang disebabkan oleh gelombang yang mengenai kapal ketika air tenang

3. Yang dipengaruhi oleh gelombang ketika berada di bawah laut bergelombang.

Ketiga komponen jika digabungkan bersama akan menghasilkan total bending moment, komponen kedua dan ketiga disebut wave bending moment.

\section{Spektrum Gelombang}

Model matematik spektrum secara umum didasarkan pada satu atau lebih parameter, misalnya tinggi gelombang signifikan, periode gelombang, faktor permukaan, dan lain-lain. Spektrum parameter tunggal yang paling sering digunakan adalah model Pierson-Moskowitz yang berdasarkan pada tinggi gelombang signifikan atau kecepatan angin. Selain itu ada beberapa spektrum parameter ganda yang bisa digunakan adalah Bretschneider (1969), Scott (1965) dan ITTC (1964). Sedangkan spektrum JONSWAP merupakan spektrum yang menggunakan lima parameter, namun biasanya tiga diantaranya adalah konstan.

Spektrum JONSWAP didasarkan pada percobaan yang dilakukan di North Sea. Formula 
atau persamaan untuk spektrum JONSWAP dapat ditulis dengan modifikasi dari persamaan spektrum Pierson-Moskowitz, yaitu:

$$
S(\omega)=\alpha g^{2} \omega^{-5} \exp \left[-1,25\left(\frac{\omega}{\omega O}\right)^{-4}\right] \gamma
$$$$
\exp \left[\frac{-(\omega-\omega)^{2}}{2 \tau^{2} \omega c^{2}}\right]
$$

Dimana:

$\gamma=$ parameter puncak (peaked-ness parameter), yang bernilai dalam range 2-3, atau dapat ditentukan dengan menggunakan rumus sebagai berikut:

$$
\begin{aligned}
& \gamma=5 ; \text { Untuk } \frac{T_{P}}{\sqrt{H_{S}}} \leq 3.6 \\
& \gamma=\operatorname{EXP}\left(5.75-1.15 \frac{T_{P}}{\sqrt{H_{S}}}\right) ; \text { Untuk } \frac{T_{P}}{\sqrt{H_{S}}}>3,6 \\
& \tau=\text { parameter bentuk (shape parameter), untuk } \\
& \omega \leq \omega_{0}=0,07 \text { dan } \omega \geq \omega_{0}=0,09 \\
& \alpha=\text { Konstanta Philips, dengan rumus }=5,058
\end{aligned}
$$

$$
\left[\frac{H_{S}}{\left(T_{P}\right)^{2}}\right]^{2}(1-0,287 \ln \gamma)
$$

namun dalam keadaan normal $\alpha=0,0081$

Dimana :

$$
\begin{aligned}
& T_{p}=\text { periode dari spectral peak } \\
& H_{s} \quad=\text { tinggi gelombang signifikan }
\end{aligned}
$$

\section{Pengumpulan Data}

\begin{tabular}{|c|c|c|c|}
\hline Description & Symbol & Unit & Quantities \\
\hline vessel size & & kDWT & 200 \\
\hline $\begin{array}{l}\text { length between } \\
\text { perpendicular }\end{array}$ & Lpp & $\mathrm{m}$ & 310 \\
\hline breadth & $\mathrm{B}$ & $\mathrm{m}$ & 47.17 \\
\hline depth & $\mathrm{H}$ & $\mathrm{m}$ & 28.04 \\
\hline production level & & bpd & 120,000 \\
\hline draft & $\mathrm{T}$ & $\mathrm{m}$ & 18.90 \\
\hline length-beam ratio & $\mathrm{L} / \mathrm{B}$ & & 6.57 \\
\hline beam-draft ratio & $\mathrm{B} / \mathrm{T}$ & & 2.50 \\
\hline displacement & & MT & 240,869 \\
\hline block coefficient & $\mathrm{Cb}$ & & 0.85 \\
\hline water plane area & A & $\mathrm{m}^{2}$ & $13,400.00$ \\
\hline $\begin{array}{l}\text { water plane } \\
\text { coefficient }\end{array}$ & $\mathrm{Cw}$ & & 0.92 \\
\hline $\begin{array}{l}\text { center of gravity } \\
\text { above base }\end{array}$ & KG & $\mathrm{m}$ & 13.32 \\
\hline $\begin{array}{l}\text { metacentric height } \\
\text { transverse }\end{array}$ & MGt & $\mathrm{m}$ & 5.78 \\
\hline $\begin{array}{l}\text { metacentric height } \\
\text { longitudinal }\end{array}$ & MGl & $\mathrm{m}$ & 403.83 \\
\hline $\begin{array}{l}\text { Transverse radius } \\
\text { of gyration }\end{array}$ & KXX & M & 14.77 \\
\hline $\begin{array}{l}\text { Longitudinal radius } \\
\text { of gyration }\end{array}$ & Куy & $\mathrm{m}$ & 77.47 \\
\hline $\begin{array}{l}\text { Yaw radius of } \\
\text { gyration }\end{array}$ & Kzz & $\mathrm{m}$ & 79.30 \\
\hline
\end{tabular}

\section{Pengumpulan Data}

Data-data yang digunakan adalah data yang bersumber dari jurnal yang akan dibahas yaitu "Hull/mooring/riser coupled dynamic analysis and sensitivity study of a tanker-based FPSO" Archandra Tahar dan M.H. Kim [1].

\section{Data FPSO}

Tabel 1. Ukuran Utama FPSO
Sumber: Kim [1]

\section{Distribusi Beban}

Tabel 2. Distribusi Beban FPSO

\begin{tabular}{lcccc}
\hline Module Name & $\begin{array}{c}\text { Beban } \\
\text { (ton) }\end{array}$ & X (m) & Y (m) & Z (m) \\
\hline Module PM-01 & 47.228051 & 221.53 & 19.846 & 43.28 \\
\hline Module PM-02 & 55.099393 & 195.16 & 19.846 & 43.28 \\
\hline Module PM-03 & 39.356709 & 175.98 & -19.85 & 43.28 \\
\hline Module PM-04 & 47.228051 & 144.81 & -19.85 & 43.28 \\
\hline Module PM-05 & 39.356709 & 108.85 & 19.846 & 43.28 \\
\hline Module PM-06 & 47.228051 & 111.24 & -19.85 & 43.28 \\
\hline Module PM-07 & 62.970735 & 82.47 & 19.846 & 43.28 \\
\hline Module PM-08 & 47.228051 & 77.68 & -19.85 & 43.28 \\
\hline Module PM-09 & 47.228051 & 44.11 & 19.846 & 33.53 \\
\hline Module PM-10 & 47.228051 & 44.11 & -19.85 & 43.28 \\
\hline Module UM-1 & 55.099393 & 257.49 & 19.846 & 43.28 \\
\hline Module UM-2 & 55.099393 & 243.11 & -19.85 & 43.28 \\
\hline Module UM-3 & 47.228051 & 207.14 & -19.85 & 43.28 \\
\hline
\end{tabular}

\section{Pemodelan}

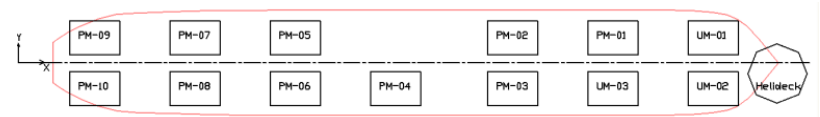

Gambar 3. Letak Module di Atas FPSO

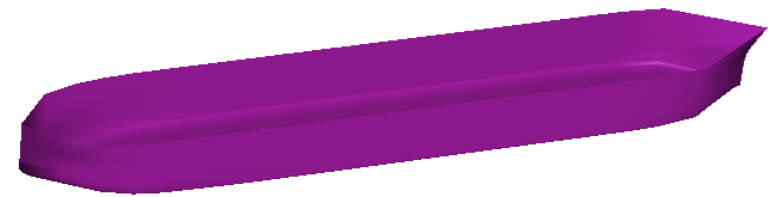

Gambar 4. Pemodelan 3 Dimensi FPSO dalam Bentuk konseptual

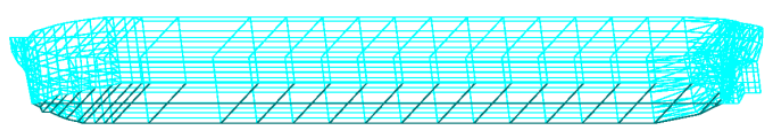

Gambar 5. Pemodelan 3 Dimensi FPSO dalam Bentuk Wireframe

\section{HASIL DAN PEMBAHASAN}

\section{Respon Kondisi Air Tenang}

Besar respon struktur FPSO dihitung dengan menggunakan pemodelan numerik. Input nilai yang digunakan adalah tinggi gelombang ekstrim, yang diambil dengan menggunakan persamaan:

$$
\boldsymbol{H}_{\text {ekstrim }}=\frac{\lambda}{\mathbf{2 0}}
$$

Dimana $\lambda$ adalah panjang gelombang, yang diasumsikan sama dengan panjang kapal, yaitu 318.9 m. Sehingga $\boldsymbol{H}_{\text {ekstrim }}=\mathbf{1 5 . 9 4 5} \boldsymbol{m}$. Keluaran dari pemodelan numeric ini adalah shear force dan bending moment pada kondisi hogging dan sagging. 
Kondisi hogging adalah kondisi dimana puncak gelombang berada di bagian tengah kapal serta kedua lembah gelombang berada di ujungujung kapal. Jika kapal disederhanakan sebagai sebuah balok panjang rata, maka balok tersebut ditumpu pada bagian tengahnya dan ditekan di kedua ujungnya. Kondisi sagging adalah kondisi puncak gelombang berada di kedua ujung kapal dan lembah gelombang berada di bagian tengah kapal. Pada kondisi sagging bagian tengah lambung melendut kebawah, struktur geladak mengalami beban tekan dan struktur dasar mengalami beban tarik.

Dari hasil pemodelan dan perhitungan, didapatkan nilai shear force dengan pemodelan numeric dan analitik seperti pada Gambar 6 .

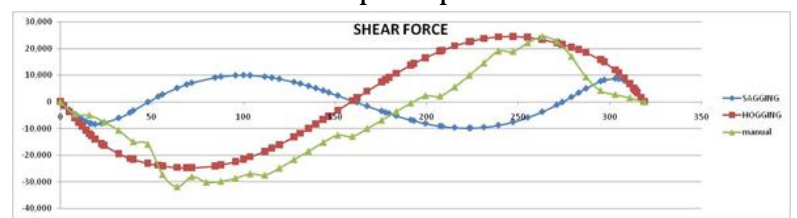

Gambar 6. Shear Force pada FPSO untuk Kondisi Hogging dan Sagging

Dari hasil pemodelan, didapatkan nilai bending moment dengan pemodelan numeric dan analitik seperti pada Gambar 7.

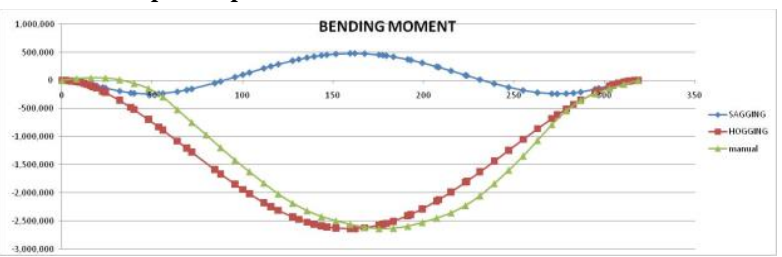

Gambar 7. Bending Moment pada FPSO untuk Kondisi Hogging dan Sagging

Shear force dan bending moment dari Pemodelan numeric merupakan fungsi kontinyu yang disebabkan karena adanya perbedaan distribusi gaya buoyancy dan berat dari FPSO. Oleh karena itu, dilakukan koreksi dengan perhitungan manual yang menunjukkan bahwa setiap station sepanjang kapal terdapat nilai shear force dan bending momen tertentu.

Karakteristik respon akibat gelombang, spectrum gelombang dan arah datang gelombang tidak diperhitungkan ketika kondisi air tenang. Analisa dinamis FPSO perlu dilakukan untuk melihat pengaruh gelombang terhadap motion dari FPSO dan pengaruh motion terhadap respon.

Pada pemodelan FPSO, koordinat local berada di AP, maka gelombang buritan adalah gelombang datang dengan sudut $180^{\circ}$, dan gelombang haluan adalah gelombang datang sudut $0^{\circ}$. Gerakan surge merupakan salah satu pola gerakan horizontal untuk kapal atau bangunan lepas pantai. Karakteristik gerakan surge didominasi oleh gelombang buritan (sudut datang gelombang $180^{\circ}$ ), kemudian gelombang haluan (sudut datang gelombang $0^{\circ}$ ). Sudut datang gelombang $150^{\circ}$ dan $30^{\circ}$ memiliki nilai yang lebih besar dibandingkan gelombang perempat haluan. Sedangkan gelombang sisi (sudut datang gelombang 90) memberikan efek yang paling kecil, dari grafik dapat dilihat bahwa nilainya hampir mendekati 0 .

\section{Respon Kondisi Bergelombang}

Dari hasil pemodelan, didapatkan nilai respon untuk 6 gerakan FPSO, antara lain: vertical, longitudinal, dan transversal force yang merupakan respon dari gerakan translasi, serta roll, pitch dan yaw moment yang merupakan respon dari gerakan rotasi.

Sumbu-x pada grafik masing-masing respon adalah frekuensi (rad/s), sedangkan sumbu-y adalah non-dimensional sesuai dengan persamaan: Untuk gaya geser:

$$
\mathrm{V}_{\mathrm{j}}^{\prime}=\frac{\zeta_{\mathrm{Vj}} \mathrm{xL}}{\zeta_{0} \mathrm{~g} \Delta}
$$

Untuk momen:

$$
M_{j}^{\prime}=\frac{M_{j}}{\zeta_{0} g \Delta}
$$

Dimana:

$$
\begin{array}{ll}
V_{j}{ }^{\prime} & =\text { Non-dimensional gaya geser } \\
\zeta_{V j} & =\text { Nilai respon gaya geser }(\mathrm{KN}) \\
L & =\text { Panjang keseluruhan kapal }(\mathrm{m}) \\
\zeta_{0} & =\text { Tinggi gelombang signifikan }(\mathrm{m}) \\
g & =\text { Gara gravitasi }\left(9.81 \mathrm{~m} / \mathrm{s}^{2}\right) \\
\Delta & =\text { displacement kapal (ton) } \\
M_{j}{ }^{\prime} & =\text { Non-dimensional momen } \\
M_{j} & =\text { Nilai respon momen (KN-m) }
\end{array}
$$

\section{Longitudinal Force}

Tabel 3 Nilai Respon Longitudinal Force pada H $15.945 \mathrm{~m}$

\begin{tabular}{lcccccccccc}
\hline \multicolumn{8}{c}{ NILAI MAKSIMUM RESPON } & DENGAN H & $\mathbf{1 5 . 9 4 5} \mathbf{~ m}$ \\
\hline Sudut Heading & $\mathbf{0}$ & $\mathbf{3 0}$ & $\mathbf{4 5}$ & $\mathbf{6 0}$ & $\mathbf{9 0}$ & $\mathbf{1 2 0}$ & $\mathbf{1 3 5}$ & $\mathbf{1 5 0}$ & $\mathbf{1 8 0}$ \\
\hline Long For & 1.969 & 1.989 & 2.558 & 2.380 & 1.969 & 2.931 & 2.625 & 2.179 & 1.845 \\
\hline Frekuensi (rad/s) & 0.610 & 0.676 & 0.676 & 0.676 & 0.757 & 0.757 & 0.676 & 0.676 & 0.610 \\
\hline
\end{tabular}

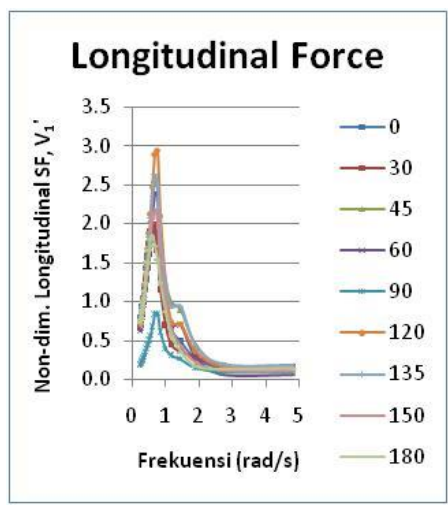

Gambar 8. Longitudinal Force pada H 15.945 m Analisa respon gaya geser longitudinal pada FPSO pada $\mathrm{H}$ maksimum berdasarkan panjang 
kapal, menunjukkan nilai maksimum pada sudut $120^{\circ}$. Gaya geser longitudinal dipengaruhi oleh gerakan surge, roll, sway dan yaw.

Gerakan surge dan sway memiliki karakteristik grafik yang hampir sama, dimana nilai maksimum berada pada frekuensi kecil/rendah. Frekuensi rendah atau frekuensi nol menunjukkan periode gelombang yang tidak terhingga atau dalam kondisi air tenang.

\section{Transversal Force}

Tabel 4. Nilai Respon Transversal Force pada $\mathrm{H}$ $15.945 \mathrm{~m}$

\begin{tabular}{lccccccccc}
\hline \multicolumn{8}{c}{ NILAI MAKSIMUM RESPON } & DENGAN H $=$ & $\mathbf{1 5 . 9 4 5}$ \\
\hline Sudut Heading & $\mathbf{0}$ & $\mathbf{3 0}$ & $\mathbf{4 5}$ & $\mathbf{6 0}$ & $\mathbf{9 0}$ & $\mathbf{1 2 0}$ & $\mathbf{1 3 5}$ & $\mathbf{1 5 0}$ & $\mathbf{1 8 0}$ \\
\hline Tran For & 0.032 & 1.921 & 3.156 & 4.644 & 9.922 & 4.318 & 3.014 & 1.721 & 0.029 \\
\hline Frekuensi (rad/s) & 0.556 & 0.556 & 0.556 & 0.556 & 0.610 & 0.556 & 0.556 & 0.556 & 0.556 \\
\hline
\end{tabular}

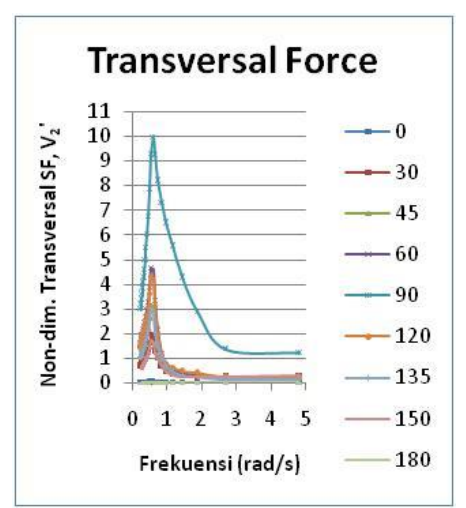

Gambar 9. Transversal Force pada H 15.945 m

Analisa respon gaya geser transversal pada FPSO untuk $\mathrm{H}$ maksimum berdasarkan panjang kapal, menunjukkan nilai maksimum pada sudut $90^{\circ}$. Gaya geser transversal dipengaruhi oleh gerakan sway.

Gerakan sway merupakan salah satu pola gerakan horizontal untuk kapal atau bangunan lepas pantai. Karakteristik gerakan sway didominasi oleh gelombang sisi (sudut datang gelombang 90\%). Pada gelombang perempat haluan intensitas respon sedikit menurun. Gerakan sway secara teoritis tidak akan terjadi pada gelombang buritan ataupun haluan, sudut datang gelombang $0^{\circ}$ dan sudut datang gelombang $180^{\circ}$ memiliki grafik yang menempel di sumbu-x grafik dan memiliki nilai respon 0 .

\section{Vertical Force}

Tabel 5 Nilai Respon Vertical Force pada H 15.945 m

NILAI MAKSIMUM RESPON DENGAN H $=15.945 \mathrm{~m}$

\begin{tabular}{lccccccccc}
\hline Sudut Heading & $\mathbf{0}$ & $\mathbf{3 0}$ & $\mathbf{4 5}$ & $\mathbf{6 0}$ & $\mathbf{9 0}$ & $\mathbf{1 2 0}$ & $\mathbf{1 3 5}$ & $\mathbf{1 5 0}$ & $\mathbf{1 8 0}$ \\
\hline Vert For & 2.095 & 2.489 & 3.267 & 4.742 & 13.088 & 4.391 & 3.089 & 2.469 & 2.027 \\
\hline
\end{tabular}

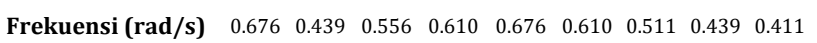

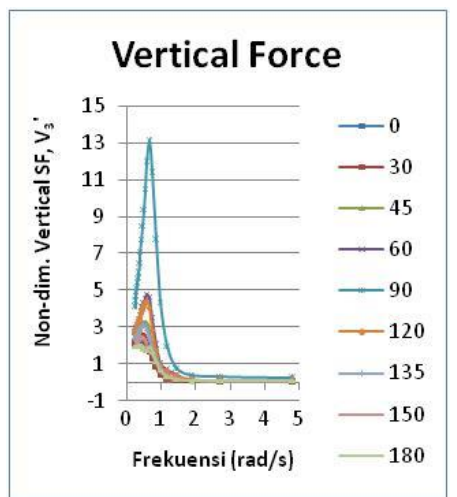

Gambar 10. Vertical Force pada H 15.945 m

Analisa respon gaya geser vertikal pada FPSO $\mathrm{H}$ maksimum berdasarkan panjang kapal, menunjukkan nilai maksimum pada sudut $90^{\circ}$. Gaya geser vertikal dipengaruhi oleh gerakan heave. Gerakan heave merupakan salah satu pola gerakan vertikal untuk kapal atau bangunan lepas pantai. Semakin kecil frekuensi maka nilai respon akan mendekati 1 atau lebih kecil dari 1, yang berarti respon struktur akibat adanya gelombang hamper tidak ada dan bahkan mengecil. Frekuensi rendah atau frekuensi nol menunjukkan periode gelombang yang tidak terhingga atau dalam kondisi air tenang. Kemudian grafik secara bertahap naik sampai mencapai puncak dan menurun lagi sampai mendekati 0 .

\section{Roll Moment}

Tabel 6. Nilai Respon Roll Moment pada H 15.945 m NILAI MAKSIMUM RESPON DENGAN H = 15.945 m

\begin{tabular}{lccccccccc}
\hline Sudut Heading & $\mathbf{0}$ & $\mathbf{3 0}$ & $\mathbf{4 5}$ & $\mathbf{6 0}$ & $\mathbf{9 0}$ & $\mathbf{1 2 0}$ & $\mathbf{1 3 5}$ & $\mathbf{1 5 0}$ & $\mathbf{1 8 0}$ \\
\hline Roll Mom & 0.000 & 0.026 & 0.040 & 0.056 & 0.099 & 0.056 & 0.040 & 0.024 & 0.000 \\
\hline Frekuensi (rad/s) & 0.556 & 0.556 & 0.556 & 0.556 & 0.556 & 0.556 & 0.556 & 0.556 & 0.556
\end{tabular}

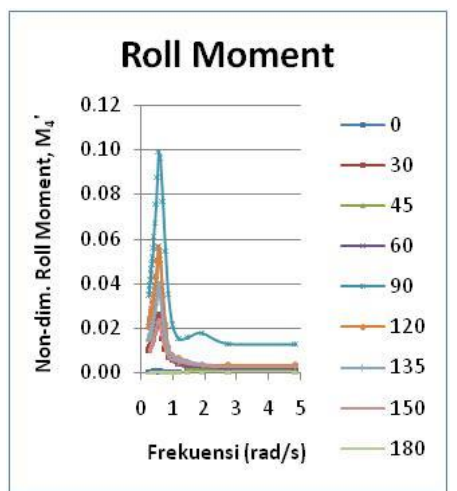

Gambar 11. Roll Moment pada H 15.945 m

Analisa respon roll moment pada FPSO untuk $\mathrm{H}$ maksimum berdasarkan panjang kapal, menunjukkan nilai maksimum pada sudut $90^{\circ}$. Roll moment dipengaruhi oleh gerakan sway, gerakan heave dan gerakan roll sendiri.

Gerakan roll merupakan mode gerakan vertikal untuk kapal atau bangunan lepas pantai. Pola perubahan respon gerakan relative sama dengan respon heave. Pada daerah sub-kritis 
respons merepresentasikan nilai yang kecil, kemudian naik tajam pada daerah resonansi, dan menurun secara signifikan pada daerah super kritis. Karakteristik gerakan roll akan didominasi oleh gelombang sisi (sudut datang gelombang 90), kemudian gelombang yang memiliki sudut sebesar $120^{\circ}$ dan $60^{\circ}$.

\section{Pitch Moment}

Tabel 7. Nilai Respon Pitch Moment pada H 15.945 $\mathrm{m}$

\begin{tabular}{lccccccccc}
\hline \multicolumn{8}{c}{ NILAI MAKSIMUM RESPON DENGAN H $=\mathbf{1 5 . 9 4 5} \mathbf{~ m}$} \\
\hline Sudut Heading & $\mathbf{0}$ & $\mathbf{3 0}$ & $\mathbf{4 5}$ & $\mathbf{6 0}$ & $\mathbf{9 0}$ & $\mathbf{1 2 0}$ & $\mathbf{1 3 5}$ & $\mathbf{1 5 0}$ & $\mathbf{1 8 0}$ \\
\hline Pitch Mom & 0.792 & 1.049 & 1.510 & 1.696 & 0.479 & 1.981 & 1.607 & 1.134 & 0.832 \\
\hline Frekuensi (rad/s) & 0.556 & 0.610 & 0.676 & 0.676 & 0.757 & 0.757 & 0.676 & 0.676 & 0.556 \\
\hline
\end{tabular}

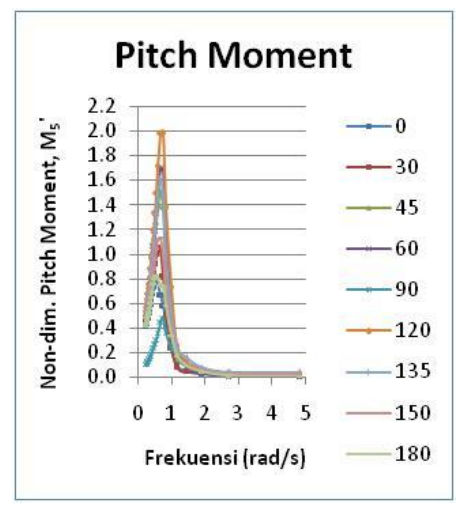

Gambar 12. Pitch Moment pada H 15.945 m

Analisa respon pitch moment pada FPSO untuk $\mathrm{H}$ maksimum berdasarkan panjang kapal, menunjukkan nilai maksimum pada sudut $120^{\circ}$. Pitch moment dipengaruhi oleh gerakan heave dan gerakan pitch sendiri. Gerakan pitch merupakan salah satu mode gerakan vertikal untuk kapal atau bangunan lepas pantai. Karakteristik gerakan pitch jika dilihat dari respon memiliki grafik yang hampir sama dengan gerakan roll, yang sama-sama merupakan mode gerakan rotasi. Karakteristik gerakan pitch akan didominasi oleh gelombang dengan sudut $120^{\circ}$, diikuti oleh gelombang dengan sudut $60^{\circ}$. Kemudian gelombang perempat buritan (sudut datang gelombang $135^{\circ}$ diikuti oleh sudut datang gelombang $45^{\circ}$ ), kemudian sudut datang gelombang $150^{\circ}$ dan $30^{\circ}$ memiliki nilai yang lebih besar dibandingkan gelombang buritan (sudut datang gelombang $180^{\circ}$ ) dan gelombang haluan (sudut datang gelombang $0^{\circ}$ ).

\section{Yaw Moment}

Tabel 8 Nilai Respon Yaw Moment pada H 15.945 m NILAI MAKSIMUM RESPON DENGAN H $=15.945 \mathrm{~m}$

\begin{tabular}{lccccccccc}
\hline Sudut Heading & $\mathbf{0}$ & $\mathbf{3 0}$ & $\mathbf{4 5}$ & $\mathbf{6 0}$ & $\mathbf{9 0}$ & $\mathbf{1 2 0}$ & $\mathbf{1 3 5}$ & $\mathbf{1 5 0}$ & $\mathbf{1 8 0}$ \\
\hline Yaw Mom & 0.006 & 0.438 & 0.591 & 0.671 & 0.040 & 0.646 & 0.586 & 0.425 & 0.006 \\
\hline Frekuensi (rad/s) & 0.610 & 0.610 & 0.610 & 0.676 & 1.461 & 0.676 & 0.610 & 0.610 & 0.610 \\
\hline
\end{tabular}

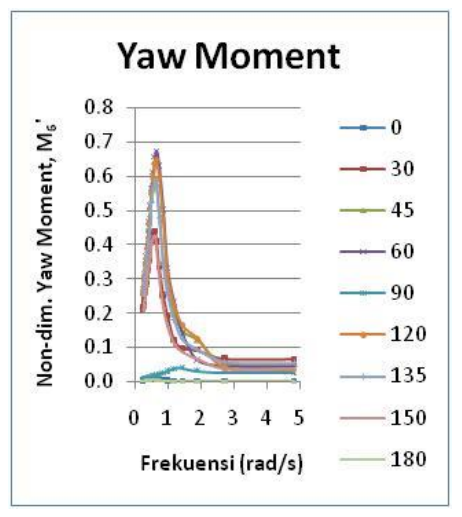

Gambar 13. Yaw Moment pada H 15.945 m

Analisa respon yaw moment pada FPSO untuk $\mathrm{H}$ maksimum berdasarkan panjang kapal, menunjukkan nilai maksimum pada sudut $60^{\circ}$. Yaw moment dipengaruhi oleh gerakan sway dan gerakan yaw. Gerakan yaw merupakan salah satu pola gerakan horizontal untuk kapal atau bangunan lepas pantai. Karakteristik gerakan surge akan didominasi oleh gelombang perempat haluan (sudut datang gelombang $45^{\circ}$ ) dan gelombang perempat buritan (sudut datang gelombang $135^{\circ}$ ). Kemudian sudut datang gelombang $60^{\circ}$ dan $120^{\circ}$, diikuti sudut datang gelombang $30^{\circ}$ dan $150^{\circ}$. Gelombang haluan dan buritan tidak memberikan pengaruh terhadap gerakan yaw.

Jika dibandingkan dengan hasil dari eksperimen dan pemodelan numerik yang dilakukan oleh Kim, dkk., dapat dilihat bahwa nilai force untuk masing-masing gerakan tidak terlalu jauh perbedaannya dibandingkan dengan hasil pada penelitian ini. Gerakan surge dominan mempengaruhi longitudinal force, gerakan sway dominan mempengaruhi transversal force, gerakan heave dominan mempengaruhi vertical force. Gerakan rotational pada FPSO menyebabkan terjadinya moment, sehingga terdapat roll moment, pitch moment dan yaw moment.

Tabel 9. Hasil Respon dari Perhitungan dalam Jurnal Kim, dkk.

\begin{tabular}{|c|c|c|c|c|c|c|c|}
\hline & & Surge $(N)$ & Sway $(N)$ & Heave $(N)$ & $\operatorname{Roll}(N-m)$ & $\begin{array}{l}\text { PITCH } \\
(N-m)\end{array}$ & $\begin{array}{l}\text { YAW } \\
(N-m)\end{array}$ \\
\hline \multirow[t]{2}{*}{ Diffraction } & Mean & $-1.05 \times 10^{6}$ & $-8.69 \times 10^{5}$ & $2.63 \times 10^{6}$ & $2.03 \times 10^{7}$ & $6.49 \times 10^{8}$ & $7.40 \times 10^{7}$ \\
\hline & St & & & & & & \\
\hline & M & -2 & & 0. & -2.15 & $-1.70 \times 10^{7}$ & -2.36 \\
\hline & $\mathrm{st}$ & & & & & 4.8 & 9.5 \\
\hline \multirow[t]{2}{*}{ Current } & Mean & -4 & $-1.99 \times$ & 9. & -1.5 & $0^{6}$ & $0^{8}$ \\
\hline & Std & & & & & $10^{6}$ & $1.77 \times 10^{4}$ \\
\hline \multirow[t]{2}{*}{ Radiation } & Mear & is & $-4.23 x$ & $8.78 \times$ & 2.16 & $-3.71 \times 10^{5}$ & $6.76 \times 10^{3}$ \\
\hline & Std & $9.61 \times 10^{\circ}$ & $6.34 \times 10^{6}$ & $2.83 \times 10^{7}$ & $1.31 \times 10^{7}$ & $5.91 \times 10^{9}$ & 1.12) \\
\hline
\end{tabular}

\begin{tabular}{lcccccc}
\hline & $\begin{array}{c}\text { Longitudinal Transversal } \\
\text { Force (N) }\end{array}$ & $\begin{array}{c}\text { Vertical } \\
\text { Force (N) }\end{array}$ & $\begin{array}{c}\text { Roll } \\
\text { Force (N) }\end{array}$ & $\begin{array}{c}\text { Poment } \\
\text { Momen }\end{array}$ & $\begin{array}{c}\text { Yaw } \\
\text { Moment } \\
\text { Moment } \\
(\mathbf{N}-m)\end{array}$ \\
\hline $\begin{array}{l}\text { Jurnal Kim, } \\
\text { dkk } \\
\text { (mean) }\end{array}$ & $1.03 \mathrm{e}+6$ & $8.69 \mathrm{e}+05$ & $2.69 \mathrm{e}+06$ & $2.03 \mathrm{e}+07$ & $6.49 \mathrm{e}+08$ & $7.40 \mathrm{e}+07$ \\
\hline $\begin{array}{l}\text { Hasil } \\
\text { pemodelan } \\
\text { (Max) }\end{array}$ & $3.53 \mathrm{e}+05$ & $1.20 \mathrm{e}+06$ & $1.58 \mathrm{e}+06$ & $3.79 \mathrm{e}+06$ & $7.61 \mathrm{e}+07$ & $2.58 \mathrm{e}+07$ \\
\hline
\end{tabular}

Dari table diatas, dapat dilihat terdapat perbedaan antara hasil eksperimen dan pemodelan numeric dari segi force untuk gerakan translasi dan rotasi. 


\section{KESIMPULAN DAN SARAN}

\section{Kesimpulan}

1. Hasil respon FPSO pada kondisi air tenang adalah pada kondisi hogging dan sagging. Terdapat perbedaan hasil antara pemodelan numerik dan perhitungan manual.

2. Respon FPSO pada saat terdapat gelombang bervariasi terhadap variasi sudut datang gelombang. Terdapat perbedaan antara hasil eksperimen dari Kim dan dari analisa numerik yang telah dilakukan.

\section{Saran}

1. Perlu dilakukan analisa motion dan respon dari FPSO based tanker dengan memperhatikan external turret mooring, dan juga membandingkan dengan system mooring lainnya

2. Perlu dilakukan pengecekan untuk distribusi pembebanan terhadap shear force dan bending moment pada pemodelan numerik

3. Perlu dilakukan optimasi kombinasi pembebanan untuk mendapatkan pembebanan maksimum yang memungkinkan dari FPSO based tanker

\section{ACKNOWLEDGMENT}

Pada kesempatan ini, penulis ingin mengucapkan terima kasih kepada semua pihak yang telah membantu penyelesaian tugas akhir ini baik secara langsung maupun tidak langsung.

\section{REFERENSI}

[1] M. H. Kim, B. J. Koo, R. M. Mercier, and E. G. Ward, "Vessel/mooring/riser coupled dynamic analysis of a turret-moored FPSO compared with OTRC experiment," Ocean Engineering, vol. 32 , no. 14 , pp. $1780-1802,2005 / 10 / 01 /$ 2005.

[2] H.-H. Sun and Y. Bai, "Time-variant reliability assessment of FPSO hull girders," Marine Structures, vol. 16, no. 3, pp. 219-253, 2003/05/01/ 2003.

[3] H. K. K. Amlashi and T. Moan, "Ultimate strength analysis of a bulk carrier hull girder under alternate hold loading condition, Part 2: Stress distribution in the double bottom and simplified approaches," Marine Structures, vol. 22, no. 3, pp. 522-544, 2009/07/01/ 2009.

[4] I. C. Clark and N. Institute, The Management of Merchant Ship Stability, Trim and Strength. Nautical Institute, 2002.

[5] R. Bhattacharyya, Dynamics of marine vehicles. Wiley, 1978.

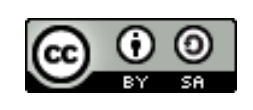

This is an open access article which means that all content is freely available without charge to the user or his/her institution. Jurnal Saintis allows the author(s) to hold the copyright without restriction. The copyright in the text of individual articles (including research articles, opinion articles, and abstracts) is the property of their respective authors distributed under the terms of the Creative Commons Attribution-ShareAlike 4.0 International License (https://creativecommons.org/licenses/by-sa/4.0/)

which permits unrestricted use, distribution, and reproduction in any medium. Users are allowed to read, download, copy, distribute, search, or link to full-text articles in this journal without asking by giving appropriate credit, provide a link to the license, and indicate if changes were made. 
J. Saintis Volume 19 Nomor 01, 2019

This page is intentionally blank 